\title{
Studies on Adelestini (Hymenoptera, Tenthredinidae), particularly the long-tongued Nipponorhynchus Takeuchi of Japan
}

\author{
David R. Smith', Tikahiko Naito² \\ I Systematic Entomology Laboratory, Agricultural Research Service, U. S. Department of Agriculture, clo Na- \\ tional Museum of Natural History, Smithsonian Institution, P.O. Box 37012, MRC 168, Washington, DC \\ 20013-7012, USA 2 Aoyama-Minami 4-13-7, Himeji-shi, Hyogo Prefecture 671-2223, Japan \\ Corresponding author: David R. Smith (sawfly2@aol.com) \\ Academic editor: M. Yoder | Received 13 June 2015 | Accepted 12 August 2015 | Published 7 September 2015 \\ http://zoobank.org/FA374BAD-F83E-4CBB-AEE2-69900D2C38F0 \\ Citation: Smith DR, Naito T (2015) Studies on Adelestini (Hymenoptera, Tenthredinidae), particularly the long- \\ tongued Nipponorhynchus Takeuchi of Japan. Journal of Hymenoptera Research 45: 1-14. doi: 10.3897/JHR.45.5442
}

\begin{abstract}
Nipponorhynchus brevis Smith \& Naito, sp. n., is described from Hokkaido, Japan. It is characterized by shorter mouthparts than those of the other two species of the genus, $N$. bimaculatus Naito and $N$. mirabilis Takeuchi. The previously unknown female of $N$. bimaculatus is described. Larvae of $N$. bimaculatus and N. mirabilis feed on Chrysosplenium macrostemon var. shiobarense (Saxifragaceae), and notes on the life history are given. Nipponorhynchus is compared with the Nearctic Adelesta Ross, the only other genus of Adelestini. A key to the genera and species of Adelestini is provided.
\end{abstract}

\section{Keywords}

Sawflies, Selandriinae, Adelesta, Chrysosplenium

\section{Introduction}

Nipponorhynchus was described by Takeuchi (1941) for a single unusual sawfly species, N. mirabilis Takeuchi, 1941, in which the maxillolabial complex is extremely elongated forming a proboscis-like structure. The mouthparts are so unique that Jervis and Vilhelmsen (2000) proposed an additional type, "Type 8," to the known seven 
functional types of elongated proboscises previously recognized among Hymenoptera. Type 8 was solely for Nipponorhynchus, and it differs from the other types by the greatly elongated prementum and stipes, together forming a structure with two food conduction channels.

A second species of Nipponorhynchus, N. bimaculatus, was added by Naito (1973), which, among other structural features, the mouthparts are elongated, but not quite as long as those of $N$. mirabilis. Here, we describe a third species with elongated mouthparts, but much shorter than the two previously described species, thus showing a gradient in length of the mouthparts from moderately to extremely long. Additionally, we also describe the female of $N$. bimaculatus for the first time.

Nipponorhynchus, known only from Japan, and the Nearctic Adelesta Ross are the only members of what is recognized as the tribe Adelestini in the Selandriinae. Though the two genera have a number of characters in common which distinguishes the tribe, we prefer to keep the two genera separate. A brief history of the tribe and key to the genera and species of the Adelestini is presented.

\section{Materials and methods}

Images for Figures 1-26 were acquired through an EntoVision micro-imaging system. This system included a Leica M16 or Leica DRMB compound microscope with an attached JVC KY-75U 3-CCD digital video camera or a GT-Vision Lw11057C-SCI digital camera, that fed image data to a notebook or desktop computer. The program Cartograph 6.6.0 was then used to merge an image series into a single in-focus image. Figures 27, 28, 30, and 31 were taken by TN using a Nikon D200 digital camera with AF Micro Nikon $200 \mathrm{~mm}$ lens. Figure 29 was taken by T. Saito using a Canon Power Shot S5 IS digital camera with a Canon Zoom 12XIS 6.0-72.0 mm lens.

Abbreviations used are: NSMT, National Museum of Nature and Science, Ibaraki, Japan; TN, collection of T. Naito, Himeji-shi, Hyogo Prefecture, Japan; USNM, National Museum of Natural History, Smithsonian Institution, Washington, DC, USA.

\section{Results}

Nipponorhynchus bimaculatus Naito

Figs 2, 6, 10, 14, 19, 23, 24, 27-29

Nipponorhynchus bimaculatus Naito, 1973: 95, fig. 1.

Description. Female: Length, $5.0 \mathrm{~mm}$. Antenna and head black; anterior half of clypeus dark brown, labrum and upper surface of maxillolabial complex whitish; palpi and undersurface of maxillolabial complex dark brown. Thorax black with tegula and posterior corners of pronotum whitish. Legs black with apices of coxae, trochanters, 

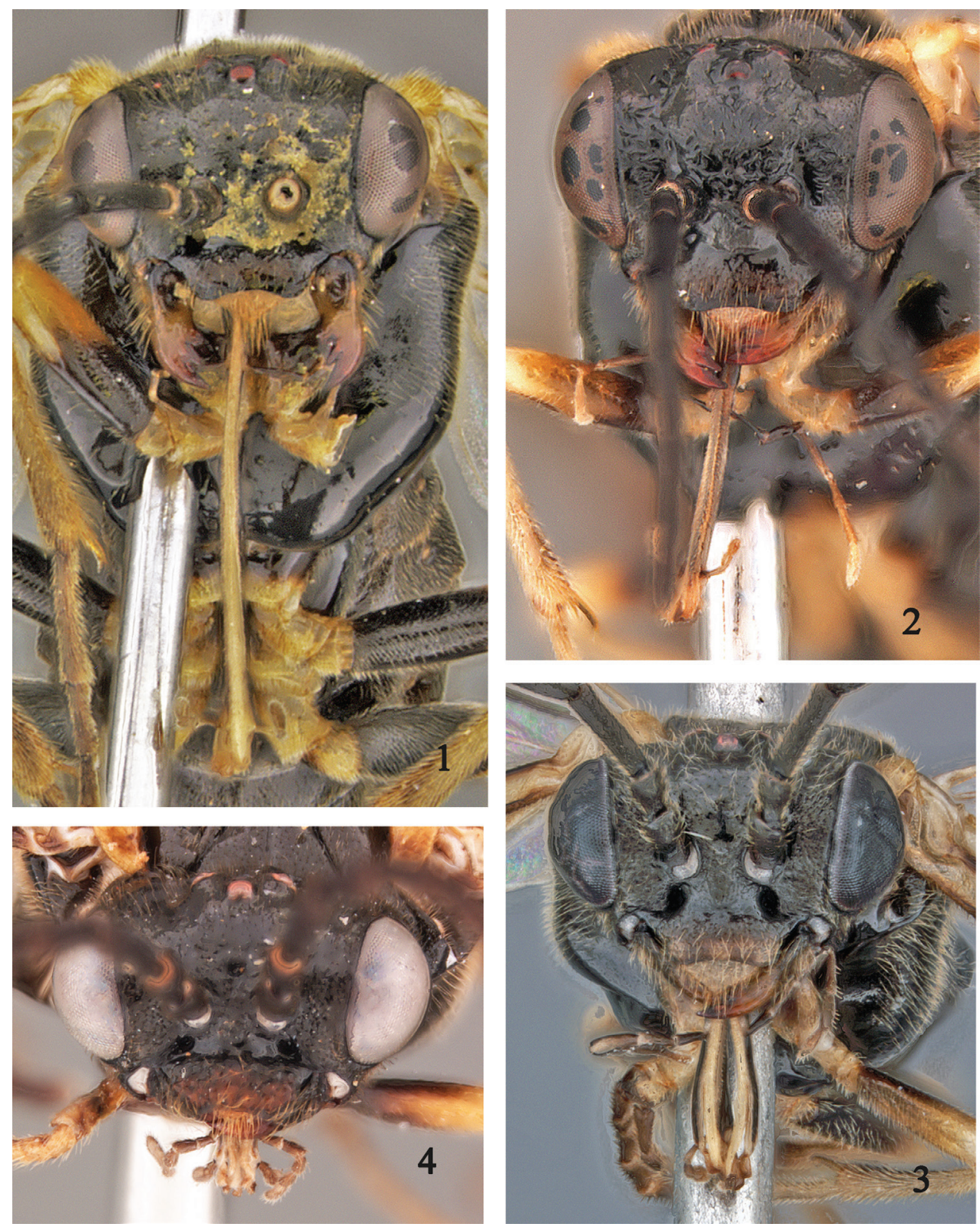

Figures I-4. Head, front view. I Nipponorhynchus mirabilis $\mathbf{2}$ N. bimaculatus $\mathbf{3}$ N. brevis 4 Adelesta nova.

apical quarter of femora, tibiae except apical quarter with black stripe on inner surface and basitarsomeres whitish. Abdomen black (terga 2 and 3 often with yellow mark in male); center of apical tergum and cercus whitish. Wings hyaline; veins and stigma black. Head very shiny, almost impunctate; inner orbits, gena and clypeus with fine irregular punctures. Thorax and abdomen very shiny, sometimes terga 3-9 finely reticulate; posterior margin of mesoscutellum with several large punctures. 
Antenna length $1.7 \times$ head width, with scape and pedicel each longer than broad; $3^{\text {rd }}$ antennomere length $1.3 \times 4^{\text {th }}, 4^{\text {th }}$ to $9^{\text {th }}$ antennomeres gradually decreasing in length. Clypeus slightly broadly, circularly emarginated, about $3 \times$ broader than long. Malar space about equal to diameter of median ocellus. Lower interocular distance $1.3 \times$ eye height; eyes only slightly converging below. Maxillolabial complex about $1.0-1.1 \times$ head width and about $2.2 \times$ eye height; maxillary palpus about $0.6 \times$ length of proboscis, longer than distance between maxillary palpus and labial palpus. Distances between eye and lateral ocellus, between lateral ocelli, and between lateral ocellus and hind margin of head as 1.0:0.8:0.5. Interocellar furrow represented by small pit. Postocellar furrow defined. Postocellar area $1.5 \times$ broader than long. Posttergite distinct, length:width as 1:4, triangular behind. Tarsal claws simple. Hind basitarsomere subequal to length of following 3 tarsomeres combined. Sheath in lateral view straight above, rounded at apex and below; from above, equally wide throughout. Lancet in Fig. 19; 10 or more annular spines in two or three rows.

Male: Described by Naito (1973). Gentialia (Figs 23, 24), penis valve with valviceps almost round and apex somewhat flattened, dorsal spine slender.

Specimens examined. JAPAN: Honshu, Bicchuzawa, Bato, Tochigi Pref. 15.IV.2004, K. Katayama (1ㅇ); same locality, 23.IV.2005, T. Naito (2今)); same locality, 24-30.IV.2005, S. Ibuki (4ㅇ), same locality, 23, 29.IV.2005, A. Shinohara (2ㅇ); same locality, 16-17.IV.2012, S. Ibuki (3ㅇ); same locality, 29.III.2012, S. Ibuki (emerged from Chrysosplenium macrostemon Maxim var. shiobarense (Franch. Hara)) (2)); Akazai-keikoku, Hyogo Pref. 20.V.1999, T. Okushima (19); Onzui-keikoku, Hyogo Pref., 21.IV.2008, T. Naito (1ㅇ); Mt. Ooginosen, Hyogo Pref., 22.V.2006, T. Naito (1, 1 đ); same locality, 7.V.2012, T. Naito; Mt. Hachibuseyama, Hyogo Pref., 5.V.2013, T. Naito (19); Honshu, Oodaigahara, Nara Pref., 7.VI.1976, T. Naito (1 ô paratype); Honshu, Bicchuzawa, Bato, Tochigi Pref., 23.IV.2005, T. Naito (2 ㅇ, 1 ठึ); Hyogo Pref., Onzui-keikoka, 700 m, 21.IV.2008, T. Naito (1 q).

Distribution. Japan (Honshu).

Host and biological notes. TN observed adult habits on the host plant in April 2005 at Bicchuuzawa, Tochigi Pref., Japan. Later, Saito and Ibuki (2010) succeeded in rearing this sawfly. Adults appear in early spring and fly on the flowers of the host plant, Chrysosplenium macrostemon Maxim var. shiobarense (Franch. Hara) (Saxifragaceae). They insert the long proboscis into the flower and absorb the nectar (Fig. 27). Females cut the seed capsule of the host plant with the sawlike ovipositor and lay their eggs into the capsule (Fig. 28). Larvae mainly eat young seeds and bracts (Fig. 29). Mature larvae fall to the ground, enter it, and make a fragile cocoon of soil particles held together by saliva (similar to $N$. mirabilis, Fig. 31). They overwinter in the prepupal stage.

The life cycle of $N$. mirabilis is quite similar to $N$. bimaculatus, and the host plant is the same for both species. The two species coexist in Honshu, Japan, where $N$. mirabilis appears somewhat earlier than $N$. bimaculatus. The body of the larva is light brown in both species, but the head is light brown in N. bimaculatus (Fig. 29), whereas it is black in N. mirabilis (Fig. 30) (Saito and Ibuki 2010). 

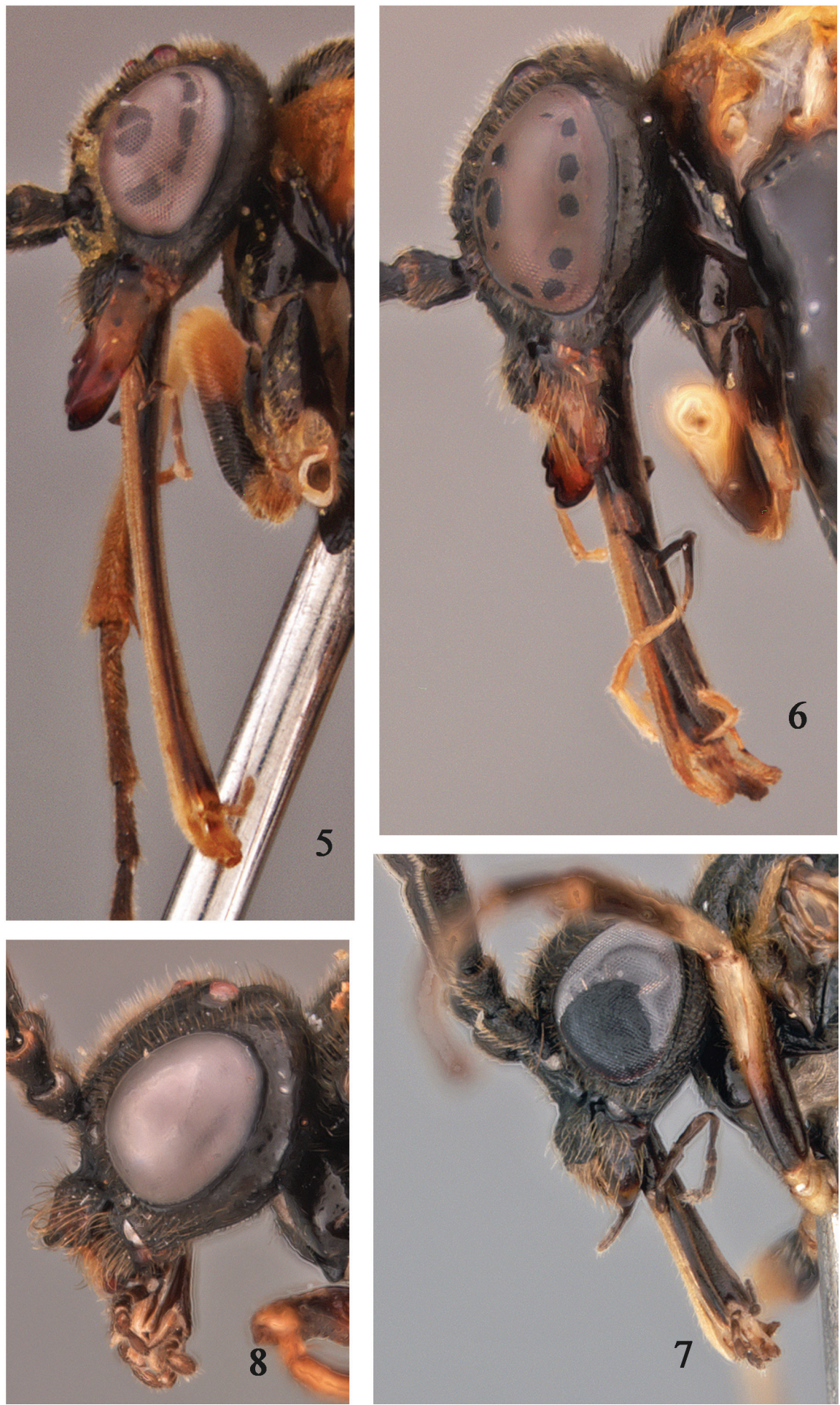

Figures 5-8. Head, lateral view. 5 Nipponorhynchus mirabilis $\mathbf{6}$. bimaculatus $\mathbf{7}$ N. brevis 8 Adelesta nova. 


\section{Nipponorhynchus brevis Smith \& Naito, sp. n.}

http://zoobank.org/937B73BC-65A3-4007-82D5-0942A3A95EC6

Figs 3, 7, 11, 15, 17, 20, 25, 26

Description. Female: Length $4.3 \mathrm{~mm}$. Antenna and head black; anterior half of clypeus light brown, labrum and upper surface of maxillolabial complex white; palpi and undersurface of maxillolabial complex black. Thorax black with tegula and posterior corners of pronotum white. Legs black with apices of coxae, trochanters, apical quarter of femora, most of tibiae except about apical quarter with black stripe on inner surface; tarsi mostly black with inner surface of first two tarsomeres paler to white. Abdomen black; apical tergum and cercus white. Wings hyaline; veins and stigma black. Head shiny but roughened with scattered fine punctures, denser on genae, postocellar area, clypeus, and above toruli. Thorax and abdomen shiny; posterior margin of mesoscutellum with several large punctures.

Antennal length $1.3 \times$ head width, with scape and pedicel each longer than broad; $3^{\text {rd }}$ antennomere slightly longer than $4^{\text {th }}, 4^{\text {th }}$ to $9^{\text {th }}$ antennomeres gradually decreasing in length. Clypeus slightly broadly, circularly emarginated, about $3 \times$ broader than long. Malar space about equal to diameter of median ocellus. Lower interocular distance $1.3 \times$ eye height; eyes only slightly converging below. Maxillolabial complex about $0.6 \times$ head width and about $1.3 \times$ eye height; maxillary palpus subequal to length of proboscis, longer than distance between maxillary palpus and labial palpus. Distances between eye and lateral ocellus, between lateral ocelli, and between lateral ocellus and hind margin of head as 1.0:0.8:0.5. Postocellar area 1.5× broader than long. Posttergite distinct, long, rounded behind. Tarsal claws simple. Hind basitarsomere subequal to length of following 3 tarsomeres combined. Pulvilli minute on tarsomeres 1-4. Sheath in lateral view straight above, rounded at apex and below (Fig. 17); from above, equally wide throughout. Lancet (Fig. 20) with about 10 spines on basal two annuli and single row of about 6 spines on remaining annuli.

Male: Length $4.1 \mathrm{~mm}$. Color and structure similar to female. Genitalia (Figs 25, 26) penis valve with valviceps elongate and rounded at apex, dorsal spine broad.

Type material. Holotype female "Japan: Hokkaido, Usubetsu, Sapporo, Ishikari, $42.9348^{\circ} \mathrm{N}, 141.1206^{\circ} \mathrm{E}, 29 . \mathrm{IV}-24 . V .2012$, small stream, Mal. trap, N. Kuhara" (NSMT). Paratypes: 4 ㅇ, 5 ô, same data as holotype (NSMT, TN, USNM).

Distribution. Japan (Hokkaido).

Etymology. From the Latin brevis, meaning short, referring to the shorter mouthparts compared to the other species.

Comments. The new species is separated from both $N$. mirabilis and $N$. bimaculatus by its shorter mouthparts. In $N$. mirabilis, the mouthparts are about $1.3 \times$ head width and 3.0x eye height (Fig.1) and in N. bimaculatus, the mouthparts are about 1.0-1.1 $\times$ head width and $2.2 \times$ eye height (Fig. 2). In Adelesta nova, the mouthparts are about $0.3 \times$ head width and $0.4 \times$ eye height (Fig. 4). It is also separated from $N$. mirabilis by the long maxillary palpus, which is longer than the distance between the maxillary palpus and labial palpus, and the longer more triangular posttergite, and 

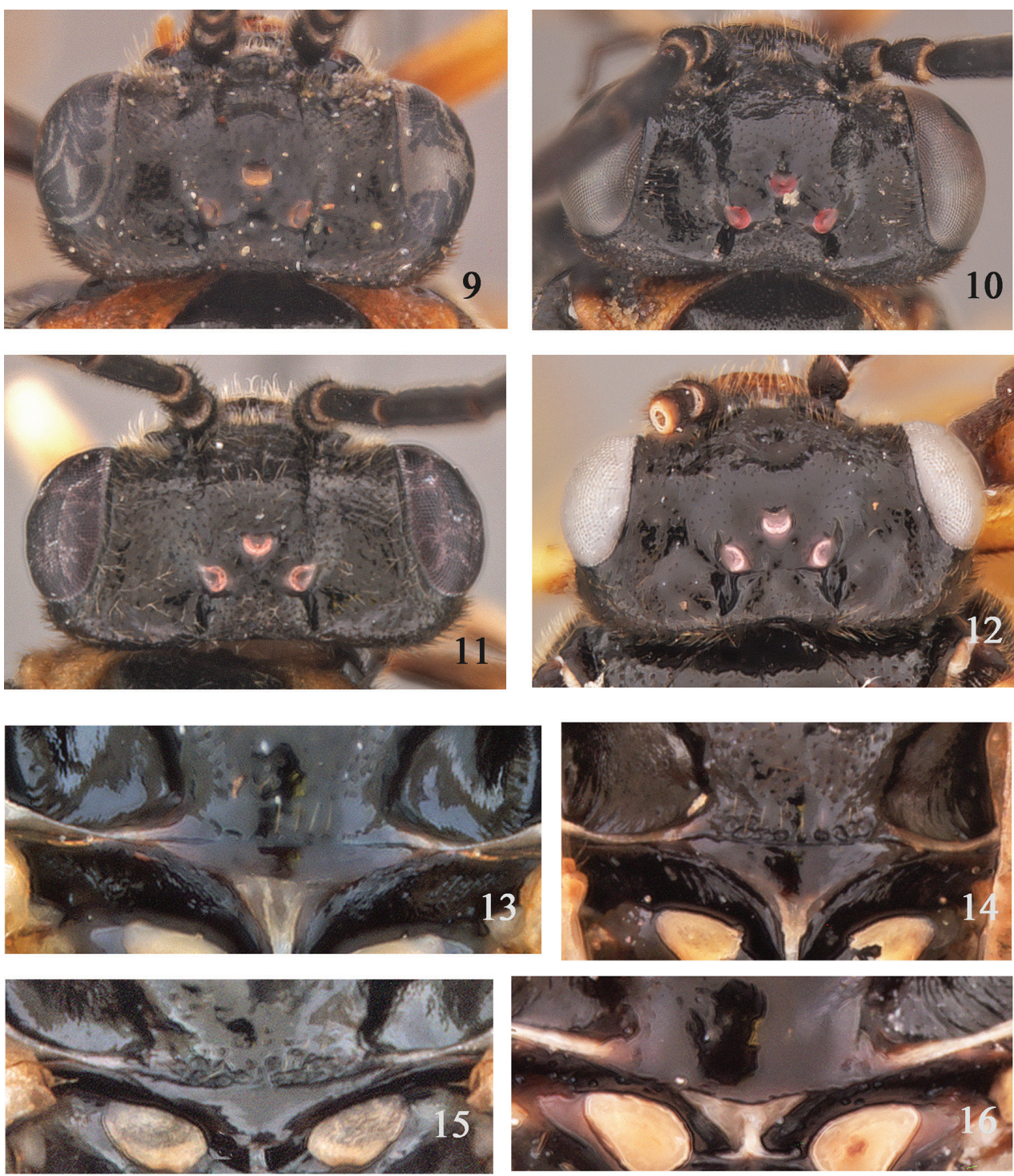

Figures 9-16. 9-12 Head, dorsal view. 13-16 Apex of mesonotum showing posttergite 9, 13 Nipponorhynchus mirabilis 10, $14 \mathrm{~N}$. bimaculatus II, $15 \mathrm{~N}$. brevis 12, 16 Adelesta nova.

from $N$. bimaculatus by the finely punctate head, which is very shiny in $N$. bimaculatus. The female lancet and male genitalia appear close to $N$. bimaculatus (Figs. 19, 20, 23-26). In N. brevis, the lancet has the basal annuli more slanted and the annuli have fewer spines, and the male penis valve is more slender and has a broader dorsal spine. All females and males of $N$. brevis studied are of the same length.

This is the first record of Nipponorhynchus from Hokkaido. The host plant is unknown. 

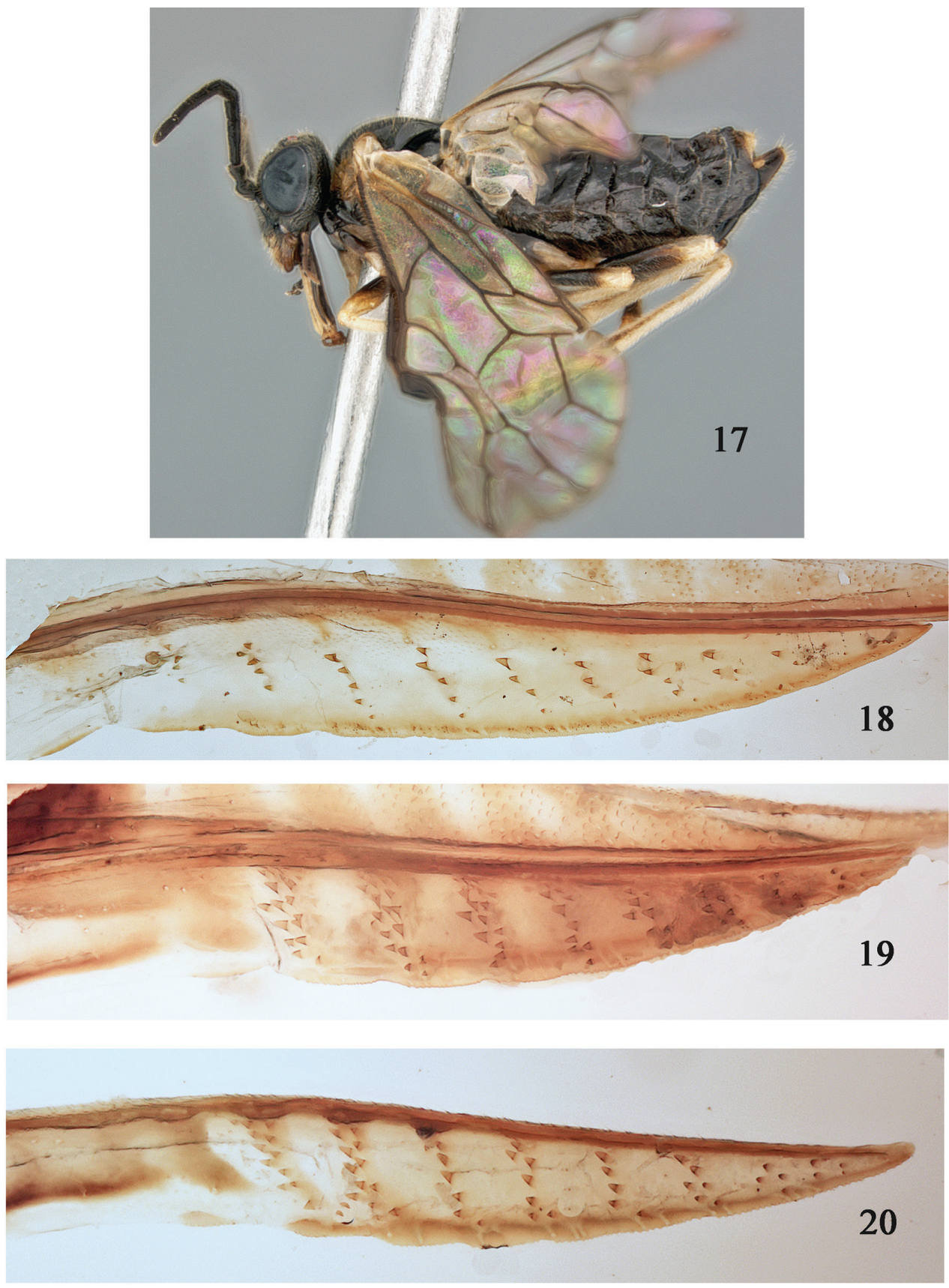

Figures 17-20. 17 Nipponorhynchus brevis, lateral view 18-20 Female lancets $18 \mathrm{~N}$. mirabilis $19 \mathrm{~N}$. bimaculatus 20 N. brevis. 

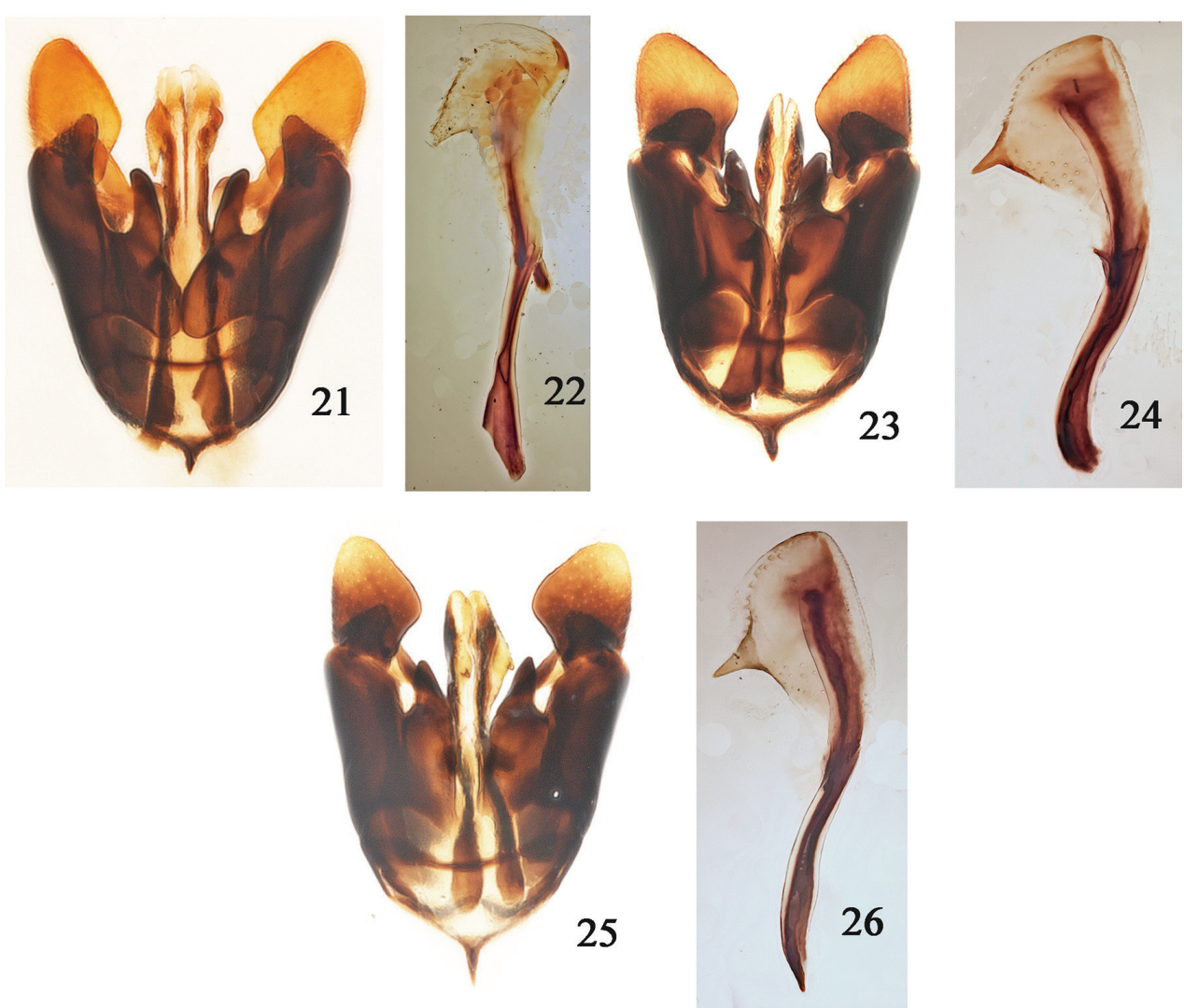

Figures 2I-26. Male genitalia. 21, 23, 25 Genital capsule, ventral view 22, 24, 26 Penis valve, lateral view 21, $22 \mathrm{~N}$. mirabilis 23, $24 \mathrm{~N}$. bimaculatus 25, $26 \mathrm{~N}$. brevis.

\section{Nipponorhynchus mirabilis Takeuchi}

Figs 1, 5, 9, 13, 18, 21, 22, 30, 31

Nipponorhynchus mirabilis Takeuchi, 1941: 233; Takeuchi and Tokunaga 1941: figs 1-7; Malaise 1963: 169, 213, figs 138-140; Naito 1973: 96, fig. 2; Jervis and Vilhelmsen 2000: 134, fig. 5 (mouthparts).

Diagnosis. Head roughened, with punctures. Maxillolabial process about $1.4 \times$ head width and $3 \times$ eye height (Figs 1, 5). Malar space longer than diameter of median ocellus. Posttergite short, narrow, of equal width throughout (Fig. 13). Lancet with single row of annular spines, not more than 4 or 5 spines on basal annuli (Fig. 18). Male genitalia (Figs 21,22) with valviceps of penis valve round.

Specimens examined. JAPAN: Mt. Ooginosen, Hyogo Pref., 900 m, 22.V.2006, T. Naito (3 $ᄋ, 1$ đ); Hyogo Pref., Akazai-keikoku, 600 m, 21.IV.2008, T. Naito (2 đ).

Distribution. Japan (Honshu). 
Host and biological notes. The host and life history are similar to those of $N$. bimaculatus. The larva (Fig. 31) also feeds on Chrysosplenium macrostemon Maxim var. shiobarense, but $N$. mirabilis occurs somewhat earlier in the season, and the head of the larva is black (Fig. 30). See notes under $N$. bimaculatus.

\section{Adelestini}

Ross (1937) first proposed the family-group name Adelestinae, including only Adelesta described at the same time, with the single species $A$. nova (Norton, 1867). $\mathrm{He}$ differentiated the subfamily by the absence of the epicnemium, the posttergite not differentiated, propleurae with the mesal margins narrow and pointed, the distal anal cell of the forewing almost as long as the proximal anal cell, and 1r-m joining Rs near separation from $\mathrm{R}$ in the hind wing.

Benson (1938) did not agree with Ross, indicating that the characters Ross used did not justify a separate category because of fluctuating morphological characters in the Selandriinae. However, his treatment as "?Adelestini" left the door open to accepting it as a possible tribe.

Takeuchi (1941) described Nipponorhynchus and Takeuchi and Tokunaga (1941) were the first to recognize that characters of Adelesta almost perfectly coincided with those of Nipponorhynchus. They placed both genera in Adelestini, one of three tribes in the Selandriinae. Their conclusion was based on Ross' (1937) description of Adelesta and not on comparison of actual specimens. The main character for the tribe was the absence of an epicnemium on the anterior part of the mesopleuron.

Ross $(1951)$ and Smith $(1969,1979)$ continued to recognize the tribe Adelestini, mainly characterized by the subserrate antennae, forewing with an anal crossvein, long distal anal cell and constriction of the basal anal cell of the forewing, absence of an epicnemium, and indistinctly defined posttergite on the mesoscutellum. Both authors based their concept only on Adelesta.

Malaise (1963) did not recognize tribes, but keyed Adelesta and Nipponorhynchus to the same couplet, separated from other genera by the scutellar appendage (posttergite) not differentiated or very narrow, front wings with short anal crossvein at about the middle of the anal cell, labrum narrow and triangular, and antennae filiform or, slightly serrated. He recognized Adelesta as having a very short perpendicular anal crossvein in the forewing and antennae stout with the pedicel about as long as wide and Nipponorhynchus with an oblique anal crossvein in the forewing and antenna slender with pedicel longer than wide. In addition, though not mentioned for Adelesta, he gave the elongated mouthparts and broadly emarginated propodeum as additional characters for Nipponohynchus.

Naito (1975) proposed a phylogeny of some related genera in Selandriinae and concluded that Nipponothynchus and Adelesta belong to a distinct clade. However, he did not assign tribal names.

Sinonerva, with the single species S. albipes, was described by Wei (1998). He compared Sinonerva with Adelesta and Nipponorhynchus and mentioned that Sinonerva differs from the two by the bidentate mandibles, second segment of the antenna longer 

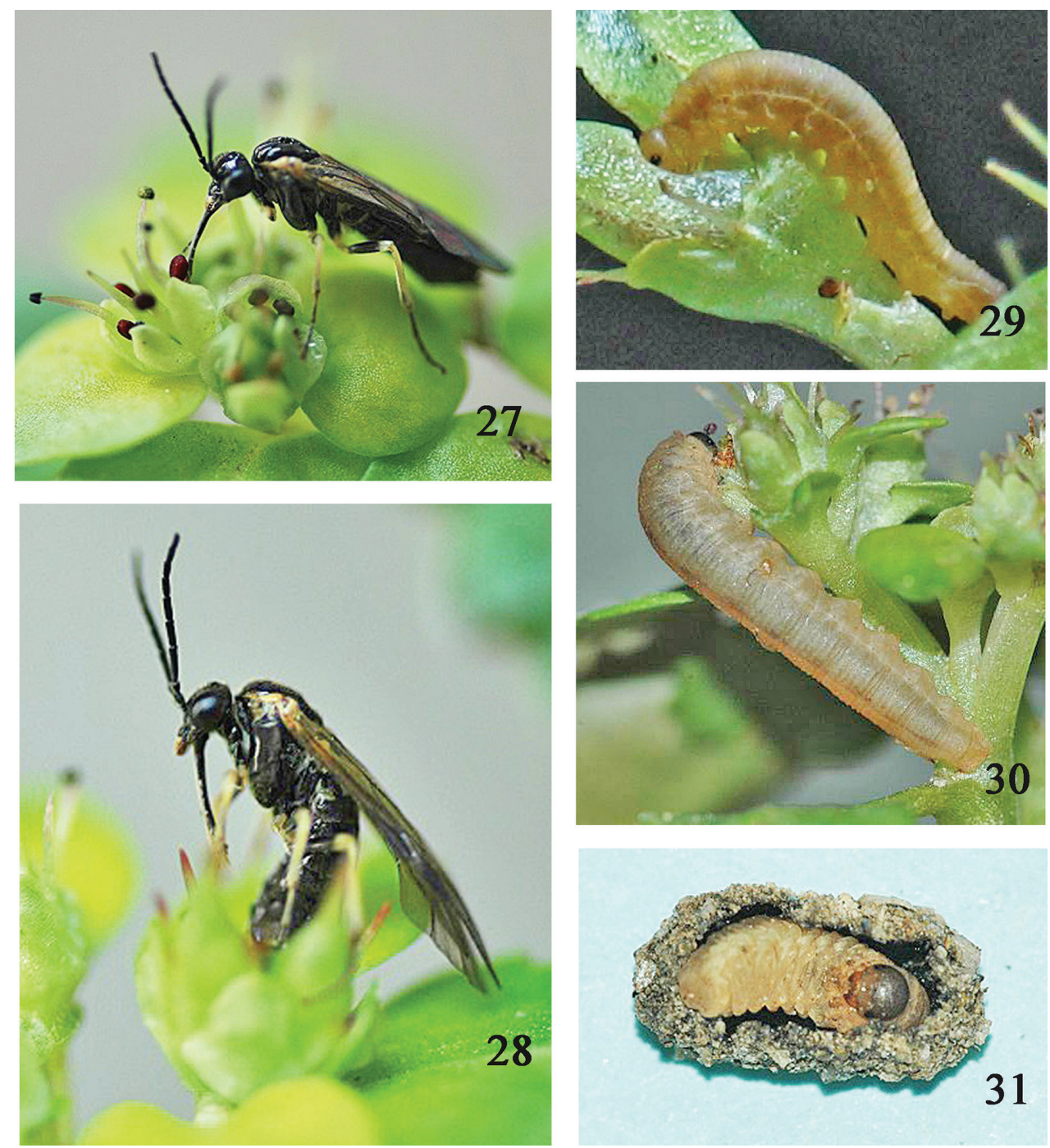

Figures 27-3I. Nipponorhynchus spp. and the host plant, Chrysosplenium macrostemon var. shiobarense. $27 \mathrm{~N}$. bimaculatus, adult drinking honey of the host plant $\mathbf{2 8} \mathrm{N}$. bimaculatus adult female ovipositing into a seed capsule of the host plant. $29 \mathrm{~N}$. bimaculatus larva eating young seeds of host plant $\mathbf{3 0} \mathrm{N}$. mirabilis, larva eating young seeds of host plant $\mathbf{3} \mathbf{I} \mathrm{N}$. mirabilis pupa in cocoon in soil.

than wide, developed epicnemium and posttergite, tarsal claws with a long inner tooth and small basal lobe, and the hind wing with cell Rs remote from vein $\mathrm{Sc}+\mathrm{R}$ and the anal cell shortly petiolate. Later, Wei and Nie (1998) placed Sinonerva in the Adelestini with Adelesta and Nipponorhynchus. We have not seen Sinonerva, but it differs from Adelesta and Nipponorhynchus in several ways. The latter two genera have tridentate mandibles, antenna with flagellum gradually reduced towards apex, epicnemium absent, tarsal claws simple, and cell Rs in hind wing elongate and very near or touching vein $\mathrm{Sc}+\mathrm{R}$. Thus, we do not include Sinonerva in Adelestini. 
We continue to recognize the Adelestini as a category in Selandriinae, separated from other Selandriinae by the presence of a short almost perpendicular anal cell in the forewing near the center of the anal cell, absence of an epicneium, an elongated maxillolabial process (the long proboscis), tridentate mandibles, lateral halves of first tergum widely separated on the meson thus exposing a broad membranous area, and simple tarsal claws. The indistinct posttergite, as mentioned by Ross (1937), Malaise (1963), and Smith (1969), is present only in Adelesta; it is well developed in Nipponorhynchus. Though not mentioned by previous authors, Adelesta does have somewhat elongated mouthparts, though not nearly as long as those in Nipponorhynchus. Though we see a gradient from the short proboscis in Adelesta nova to the unusually elongated proboscis in Nipponorhynchus mirabilis, and Adelesta and Nipponorhynchus share many characters in common, they can still be distinguished from each other by the shape of the posttergite, length of the mouthparts, antennae, placement of the anal crossvein in the forewing, and the shape of clypeus, and we choose to continue to keep them separate. The two genera and species can be separated by the following key.

\section{Key to genera and species of Adelestini}

$1 \quad$ Posttergite very narrow, of equal width throughout (Fig. 16); mouthparts short, less than eye length and about $0.3 \times$ head width (Figs 4, 8); apical labial palpomeres enlarged, palpi appear capitate; anal cell of forewing perpendicular, placed basally of the middle of the anal cell; antenna stout, antennomeres 4-9 at most $2 \times$ longer than broad; clypeus about $2 \times$ broader than long; eastern North America

Adelesta nova

- $\quad$ Posttergite distinct, long, longer at center than at sides (Figs 13-15); mouthparts exceptionally developed, half or more head width and longer than eye height (Figs 1-3, 5-7); labial palpomeres about equal in size; anal cell of forewing slightly slanted, placed at center of anal cell; antenna slender, antennomeres 4-9 more than $2 \times$ longer than broad; clypeus about $3 \times$ broader than long; Japan; Nipponorhynchus.

2 Maxillolabial complex short, about $0.6 \times$ head width and about $1.3 \times$ eye height (Figs 3, 7); maxillary palpus long, longer than distance between maxillary palpus and labial palpus

- Maxillolabial complex longer, 1.1 to $1.4 \times$ head width and $2 \times$ or more eye height (Figs 1, 2, 5, 6); length of maxillary palpus various 3

3 Posttergite long, triangular, longer at center than at sides (Fig. 14); head shiny; maxillolabial process subequal to head width and about $2 \times$ eye height (Figs 2 , 6); malar space about equal to diameter of median ocellus .....N. bimaculatus

- $\quad$ Posttergite short, narrow, of equal width throughout (Fig. 13); head roughened, with punctures; maxillolabial complex about $1.4 \times$ head width and $3 \times$ eye height (Figs 1, 5); malar space longer than diameter of median ocellus..... N. mirabilis 


\section{Acknowledgments}

We thank T. Saito for allowing use of the photograph of the larva of $N$. bimaculatus (Fig. 29) and E. Talamas, Systematic Entomology Laboratory, USDA, Washington, DC, for help with some of the images. Mention of trade names or products in the publication is solely for the purpose of providing specific information and does not imply recommendation or endorsement of the USDA. The USDA is an equal opportunity provider and employer.

\section{References}

Benson RB (1938) On the classification of sawflies (Hymenoptera: Symphyta). Transactions of the Royal Entomological Society of London 87: 353-384.

Jervis M, Vilhelmsen L (2000) Mouthpart evolution in adults of the basal, "symphytan", hymenopteran lineages. Biological Journal of the Linnean Society 70: 121-146.

Malaise R (1963) Hymenoptera Tenthredinoidea, subfamily Selandriinae, key to genera of the world. Entomologisk Tijdskrift 84: 159-216.

Naito T (1973) A new species of Nipponorhynchus Takeuchi from Japan (Hymenoptera: Tenthredinidae. Kontyû 41: 95-96.

Naito T (1975) Phylogeny and distribution of five related genera, Eriocampidea, Hemitaxonus, Pseutohemitaxonus, Nipponorhynchus and Adelesta, referred to the Selandriinae (Hymenoptera, Tenthredinidae). Kontyû 43: 330-342.

Norton E (1867) Catalog of the described Tenthredinidae and Uroceridae of North America. Transactions of the American Entomological Society 1: 193-280.

Ross HH (1937) A generic classification of the Nearctic sawflies (Hymenoptera: Symphyta). Illinois Biological Monographs 34, 173 pp.

Ross HH (1951) Tenthredinidae. In: Muesebeck CFW, Krombein KV, Townes HK (Eds) Hymenoptera of America North of Mexico, Synoptic Catalog. United States Department of Agriculture, Agriculture Monograph 2, 22-82.

Saito T, Ibuki S (2010) [Biological notes on the sawfly genus Nipponorhynchus at Bicchuzawa, Nakagwa-cho, and Yamaguchi, Nikko-shi, in Tochigi Pref.]. Insekuto 61: 101-107. [In Japanese]

Smith DR (1969) Nearctic sawflies II. Selandriinae: Adults (Hymenoptera: Tenthredinidae). United States Department of Agriculture, Technical Bulletin No. 1398, 48 pp., 10 pls.

Smith DR (1979) Symphyta. In: Krombein KV, Hurd PD Jr., Smith DR, Burks BD (Eds) Catalog of Hymenoptera in America north of Mexico, Volume 1, Symphyta and Apocrita (Parasitica). Smithsonian Institution Press, Washington, D.C., 3-137.

Takeuchi T (1941) A systematic study on the suborder Symphyta of the Japanese Empire (IV). Tenthredo 3: 230-274.

Takeuchi K, Tokunaga M (1941) Morphological study of head and mouthparts of a remarkable saw-fly, Nipponorhynchus mirabilis Takeuchi. Tenthredo 3: 275-291. 
Wei M (1998) A new genus and species of Selandriidae of China (Hymenoptera: Tenthredinomorpha). Journal of Central South Forestry University 18: 1-3.

Wei M, Nie H (1998) Generic list of Tenthredinoidea s. str. (Hymenoptera) in new systematic arrangement with synonyms and distribution data. Journal of Central South Forestry University 18: 23-31. 